\title{
МЕТОДИКА ОПРЕДЕЛЕНИЯ РАЦИОНАЛЬНОСТИ ФИНАНСИРОВАНИЯ НА СУБФЕДЕРАЛЬНОМ УРОВНЕ С ПОЗИЦИЙ РАВНОВЕСИЯ РАЗВИТИЯ
}

\author{
В. А. Бубнов \\ Иркутский государственный университет путей сообщения, , г. Иркутск, Российская Федерация
}

Информация о статье

Дата поступления

5 июня 2017 г.

Дата принятия к печати 7 июля 2017 г.

Дата онлайн-размещения 15 сентября 2017 г.

\section{Ключевые слова \\ Рациональное финансирование; субфедеральный уровень; индикаторы развития; уровень рациональности финансирования; признаки и принципы рационального финансирования}

\begin{abstract}
Аннотация
Вводится понятие «рациональное фринансирование», обозначены его признаки и принципы. Разработана методика определения уровня рациональности финансирования на субфедеральном уровне на основе системы индикаторов по следующим направлениям: демографические и трудовые, социальные, экономические, уровень жизни населения, инфраструктурные и финансовые. По каждому из направлений сформировано по десять индикаторов. Данная методика апробирована на примере субъектов Федерации, входящих в Сибирский федеральный округ, в период 1990-2013 гг. Представлены результаты исследования по каждому направлению, что позволяет детально представить картину комплексного развития Сибири. Делается акцент на необходимости изучения рациональности финансирования и использования методики определения ее уровня для выравнивания условий проживания в России.
\end{abstract}

\section{METHODOLOGY OF DETERMING FINANCING RATIONALITY AT THE SUBFEDARAL LEVEL IN TERMS OF THE DEVELOPMENT EQUILIBRIUM}

\author{
Vyacheslav A. Bubnov \\ Irkutsk State Railway Transport Engineering University, Irkutsk, Russian Federation
}

\section{Article info}

Received

June 5, 2017

Accepted

July 7, 2017

Available online

September 15, 2017

\section{Keywords}

rational financing; subfederal level; development indicator; degree of financing rationality; features and principles of financing

\begin{abstract}
In the present paper a notion of rational financing is introduced and its features and principles are described. A methodology of determining the degree of financing rationality at the subfederal level is developed on the basis of the system of indicators in accordance with focus areas: demographic, social, economic, infrastructural, financial, workforce and living standard, with ten indicators for each of the above areas. The suggested methodology was tested through the example of the Russian Federation subjects of the Siberian Federal District for the period of 1990-2013. Results of each area analysis are presented in the paper providing an insight into the integrated development of Siberia. It is highlighted that, in order to make all places of Russia equally livable, it is necessary to study rationality of financing and apply the given methodology to determine the financing rationality degree.
\end{abstract}

В условиях продолжающегося снижения темпов роста российской экономики в связи с волатильностью цен на сырье становится ясно, что Россия с односторонней экспортной ориентацией в данный период наиболее уязвима. Отсутствие институтов развития и несорормированность государственной политики в отношении комплексного развития приводят к резкой диффреренциации на субфедеральном уровне. Полагаем, что рациональное финансирование позволит стимулировать развитие в противовес общему финансированию, обеспечивающему распределительную функцию финансов, что основывается на советском финансовом опыте и одновременно современном «псевдорыночном» методе [1]. 
C нашей точки зрения, рациональное финансирование - процесс обеспечения денежными средствами и иными активами расширенного воспроизводства развития общества. Согласимся с позицией Ю. Г. Швецова, согласно которой «государственные финансовые ресурсы могут и должны стать своеобразным катализатором модернизационных процессов экономики и сглаживания чрезмерных различий» [2]. По нашему мнению, рациональное финансирование имеет следующие характеристики, представленные в схематичном виде в табл. 1.

В отличие от традиционного подхода к финансированию, применяемого для решения совокупности текущих проблем, рациональное финансирование направлено на достижение целевых ориентиров, что, в свою очередь, позволяет решить и комплекс текущих проблем (рис. 1).

Процесс рационального финансирования в любом государстве имеет свои особенности, исторически обусловленные институциональным развитием. Развитие финансирования прошло этапы, представленные на рис. 2. Считаем, что первичной фрормой было финансирование домашних хозяйств и до создания
Конституции «все существующие фринансы так или иначе были финансами домашних хозяйств» [3]. По мере усложнения общественных отношений и развития мировой торговли происходило усиление государственных институтов и нивелирование роли финансирования домашних хозяйств, что привело к появлению публичных (государственных) фринансов.

Предоставление государством гарантий на право частной собственности для экономических институтов привело к формированию крупного капитала, который способствовал созданию корпоративного финансирования. В начале XXI в. мы наблюдали развитие глобального финансирования, охватившего развитые и развивающиеся страны. Оно формирует наднациональные институты, цели деятельности которых являются отдельным предметом исследования. Мировой финансовый кризис, начавшийся в 2008 г. и продолжающийся и поныне, поставил под сомнение рациональность и эффективность глобального финансирования как с общемировых позиций, так и для отдельных стран. Распределение ролей в глобальном финансировании не способствует экономическому развитию большинства стран мира.

Таблица 1

Основные различия категорий «финансирование» и «рациональное финансирование» с позиций развития на субфедеральном уровне

\begin{tabular}{|l|l|l|}
\hline \multicolumn{1}{|c|}{ Финансирование } & \multicolumn{1}{|c|}{ Показатель } & \multicolumn{1}{|c|}{ Рациональное финансирование } \\
\hline $\begin{array}{l}\text { Экономический рост или экономическое } \\
\text { развитие }\end{array}$ & Цель & Комплексное развитие \\
\hline Воспроизводственный процесс & Объект & Расширенное воспроизводство \\
\hline Участники экономического процесса & Субъект & $\begin{array}{l}\text { Государственный сектор или сектор } \\
\text { государственных интересов }\end{array}$ \\
\hline Иррациональный и процессный & Принцип осуществления & Рациональный и проектный \\
\hline Обеспечение финансовыми ресурсами & $\begin{array}{l}\text { Механизм осущест- } \\
\text { вления }\end{array}$ & Финансирование ключевых направлений \\
\hline $\begin{array}{l}\text { Необходимость инвестирования финансо- } \\
\text { вых ресурсов вследствие инфляционного } \\
\text { обесценения денежных средств }\end{array}$ & $\begin{array}{l}\text { Обеспечивающие } \\
\text { факторы }\end{array}$ & $\begin{array}{l}\text { Достижение целевых индикаторов, } \\
\text { определенных общественными } \\
\text { институтами }\end{array}$ \\
\hline $\begin{array}{l}\text { Денежно-кредитная и бюджетно-налого- } \\
\text { вая политика }\end{array}$ & Инструменты & $\begin{array}{l}\text { Проектное финансирование на основе } \\
\text { типологизации субфедерального уровня }\end{array}$ \\
\hline
\end{tabular}

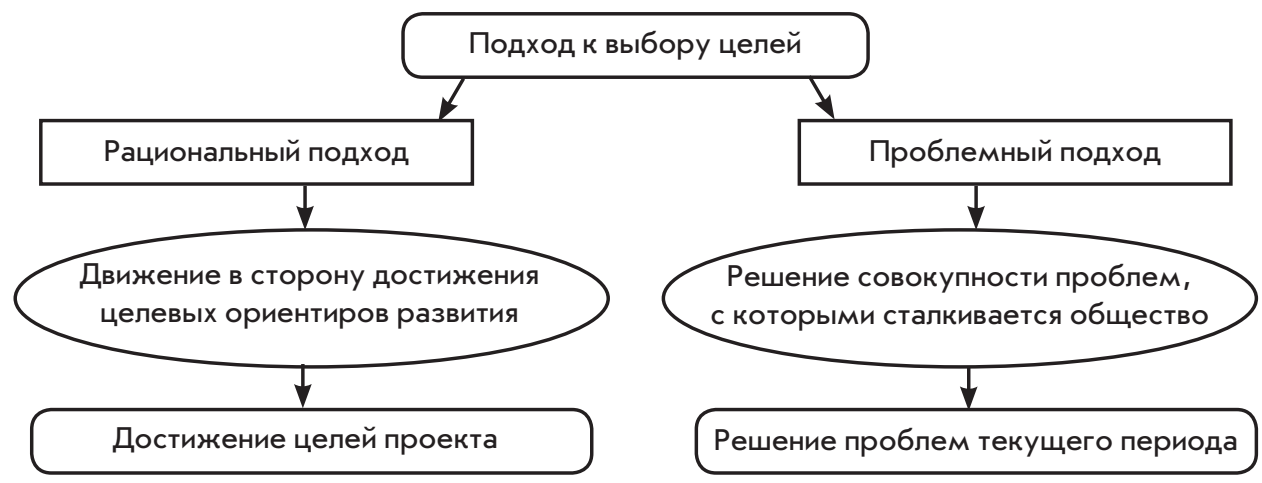

Рис. 1. Выбор целей финансирования 


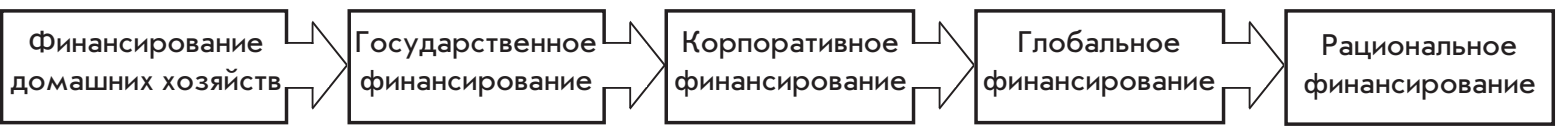

Рис. 2. Этапы формирования финансирования

Рациональное финансирование является действенным инструментом выравнивания складывающихся диспропорций. По нашему мнению, современное финансирование регионального социально-экономического развития имеет собственные признаки: множество источников, которые как подконтрольны на региональном уровне, так и нет; нестабильность структуры и объемов финансовых ресурсов ${ }^{1}$; ярко выраженная социальная направленность; законодательное регулирование, которое контролируется федеральным центром; необходимость включения субфедеральных целей в федеральные приоритеты; персональная ответственность региональных органов власти за своевременное выполнение обещаний федерального центра; отсутствие увязки объемов региональных финансовых ресурсов и принятых на себя финансовых обязательств ${ }^{2}[4]$.

«Постоянное реформирование налоговой и бюджетной систем, зачастую несбалансированное между собой, привело к тому, что региональные и местные бюджеты не смогли обеспечить себя достаточным количеством финансовых ресурсов для выполнения своих бюджетных обязательств» [там же]. Это предопределяет особенности

${ }^{1}$ Консолидированный бюджет Российской Федерации и бюджетов государственных внебюджетных фондов в 2014 г. (млрд рублей) / / Федеральное казначейство. M., 2017. URL: http://www.gks.ru/free_doc/ new_site/finans/fin21.htm.

$\overline{2}$ Исполнение консолидированного бюджета субъекта Российской Федерации в 2014 году // Российская газета. 2015. 10 марта. URL: http://www.rg.ru/ printable/2015/03/10/statistika-dok.html. финансирования развития на субфедеральном уровне:

- субфедеральный уровень должен решать социальные задачи;

- субъект Федерации финансово не может реализовать инвестиционный проект, способный генерировать экономический рост;

- только федеральный округ может реализовать любую концепцию развития на суборедеральном уровне;

- реализация инновационного проекта требует комплексного подхода;

- фринансирование социально-экономического развития на субфедеральном уровне зависит от федерального центра.

Следует учитывать различия направлений финансирования, которые фрормируются (табл. 2). Например, «сворачивание проектов, связанных с достижением социальных норм» [5] нецелесообразно, а результат неопределим. И в противовес, фринансирование экономики уменьшить реалистично, но экономический рост сократится и риски усилятся.

Выбор цели и индикаторов для разработки рационального финансирования невозможен без оценки текущей ситуации и анализа динамики различных показателей. Кроме того, присутствуют искусственно создаваемые векторы развития (Москва, Санкт-Петербург, Чечня, Хабаровский край и Республика Крым). В рамках данного научного исследования мы не будем углубляться в причины этого, тем не менее перечислим тренды фринансирования развития суборедерального уровня России в нынешнем веке:

Таблица 2

Различия направлений финансирования на региональном уровне

\begin{tabular}{|l|c|c|c|}
\hline \multirow{2}{*}{\multicolumn{2}{|c|}{ Показатель }} & \multicolumn{2}{c|}{ Финансирование } \\
\cline { 2 - 4 } & социальных норм & социально-экономического развития & экономики \\
\hline Финансовый результат & - & $-/+$ & + \\
\hline Целевой характер & + & + & + \\
\hline Риски & - & + & - \\
\hline Стабильность источника & + & + & - \\
\hline $\begin{array}{l}\text { Влияние источника фринансирования } \\
\text { на управление }\end{array}$ & + & + & + \\
\hline Возможность закрыть проект & - & + & + \\
\hline
\end{tabular}


1. Снижение объемов финансирования развития субъектов Федерации, ликвидация Минрегионразвития в соответствии с указом Президента Рф 3 .

2. Усложнение институтов финансирования субъектов Федерации. Например, сейчас пять фредеральных министерств ответственны за региональное развитие, что существенно затруднит процесс финансирования.

3. Увеличение, по данным Счетной палаты, регионального долга, количества регионов с дефицитным бюджетом: «...в 2011 г. с дефицитом были исполнены бюджеты в 57 регионах... в 2012 г. таких насчитывалось уже 67, в 2013 г. - 77, при этом дефицит консолидированных бюджетов возрос в 2,3 раза, объем государственного и муниципального долга увеличился на 27 \%» [6].

4. Либерализация публичных фринансов относительно влияния на развитие субфедерального уровня.

Несмотря на множество рейтингов, они не позволяют выделить определенный период и оценить уровень комплексного развития региона с точки зрения финансирования по всем звеньям финансовой системы. По нашему мнению, рационально рассматривать не конкурентоспособность субъекта Федерации, а уровень рациональности финансирования. В данном процессе предлагаем выделить следующие этапы.

Первый этап. Создание индикаторов развития по следующим назначениям:

1. Демографические и трудовые: 1) общие показатели рождаемости; 2) общие показатели смертности; 3) коэффрициенты младенческой смертности; 4) ожидаемая продолжительность жизни при рождении; 5) соотношение числа браков и разводов; 6) коэфффициент миграционного прироста; 7) уровень экономической активности населения; 8) уровень безработицы; 9) численность незанятых граждан, зарегистрированных в государственных учреждениях службы занятости населения, в расчете на одну заявленную вакансию; 10) число зарегистрированных преступлений на 100 тыс. чел. населения.

2. Социальные: 1) охват детей дошкольными образовательными учреждениями; 2) средняя наполняемость классов в государственных и муниципальных дневных образовательных учреждениях; 3) выпуск квалифицированных рабочих на 10 тыс. чел. занятого населения; 4) численность студентов государственных и муниципальных учреждений

3 Об упразднении Министерства регионального развития Российской Федерации : указ Президента РФ от 8 сент. 2014 г. № 612 / / СПС «КонсультантПлюс». среднего профрессионального образования на 10 тыс. чел. населения; 5) численность студентов учреждений высшего образования на 10 тыс. чел. населения; 6) число больничных коек на 10 тыс. чел. населения; 7) мощность врачебных амбулаторно-поликлинических учреждений на 10 тыс. чел. населения; 8) численность врачей на 10 тыс. чел. населения; 9) численность среднего медицинского персонала на 10 тыс. чел. населения; 10) заболеваемость на 1 тыс. чел. населения.

3. Экономические: 1) ВРП на душу населения; 2) индекс физического объема ВРП; 3) фактическое конечное потребление домашних хозяйств на душу населения на территории субъектов РФ; 4) стоимость основных фондов на душу населения; 5) степень износа основных фондов; 6) индексы промпроизводства; 7) индексы производства по виду экономической деятельности «Добыча полезных ископаемых»; 8) индексы производства по виду экономической деятельности «Обрабатывающие производства»; 9) индексы производства по виду экономической деятельности «Производство и распределение электроэнергии, газа и воды»; 10) индексы производства продукции сельского хозяйства.

4. Уровень жизни населения: 1) среднедушевые денежные доходы населения; 2) среднемесячная номинальная начисленная заработная плата работников организаций; 3) средний размер назначенных пенсий; 4) численность населения с денежными доходами ниже величины прожиточного минимума; 5) потребительские расходы в среднем на душу населения; 6) число собственных легковых автомобилей на 1 тыс. чел.; 7) общая площадь жилых помещений, приходящаяся в среднем на одного жителя; 8) численность зрителей театров на 1 тыс. чел. населения; 9) число посещений музеев на 1 тыс. чел.; 10) выпуск газет на 1 тыс. чел. населения.

5. Инфрраструктурные: 1) густота железнодорожных путей общего пользования; 2) густота автодорог общего пользования с твердым покрытием; 3) удельный вес автодорог с твердым покрытием в общей протяженности автодорог общего пользования; 4) число ДТП и пострадавших в них; 5) доходы от услуг связи населению в расчете на одного жителя; 6) наличие квартирных телефонных аппаратов сети общего пользования на 1 тыс. чел. ; 7) число ПК на 100 работников; 8) число ПК с выходом в Интернет на 100 работников; 9) оборот розничной торговли на душу населения; 10) объем платных услуг на душу населения. 
6. Финансово-инвестиционные: 1) ввод в действие жилых домов на 1 тыс. чел. населения; 2) удельный вес жилых домов, построенных населением за счет собственных и заемных средств, в общем объеме вводимого жилья; 3) удельный вес убыточных организаций; 4) инвестиции в основной капитал на душу населения; 5) индекс физического объема инвестиций в основной капитал; 6) индексы потребительских цен; 7) индексы цен производителей промышленных товаров; 8) индексы цен производителей сельскохозяйственной продукции и приобретения товаров и услуг сельскохозяйственных организаций; 9) индексы цен производителей в строительстве; 10) индексы тарифов на грузовые перевозки.

Отбор индикаторов из всей совокупности статистических показателей мы производили исходя из того, что «все фракторы или явления, так или иначе, взаимосвязаны - прямо или косвенно, непосредственно или опосредованно» [7].

Второй этап. Сравнение общероссийского индикатора и индикатора субфедерального уровня:

$$
b_{i j}^{k}=\left\{\begin{array}{l}
0, \text { общероссийский индикатор } \\
>\text { индикатор региона } \\
1_{i j}^{k}
\end{array},\right.
$$

где $i$ - номер категории $\varepsilon[1 ; 6] ; j-$ номер индикатора $\varepsilon[1 ; 10] ; k-$ регион Российской Федерации; $b_{i j}^{k}$ - балл $i$-го индикатора $j$-й категории k-го региона Российской Федерации.

$$
S_{i}^{k}=\sum_{i} b_{i j}^{k}
$$

где $S^{k}-$ вес по категории; $S_{i}^{k}-$ вес по категории.
Третий этап. Подготовка итоговых данных за период 1990-2013 гг. по каждому индикатору, а затем в целом по направлению:

$$
S^{K}=\sum_{i} \sum_{j} b_{i j}^{k}
$$

Четвертый этап. Определение рациональности финансирования на субфедеральном уровне РФ.

Пятый этап. Формирование рейтинга рациональности фринансирования на субфедеральном уровне РФ.

В данном исследовании определена рациональность финансирования федеральных округов и субъектов Федерации, входящих в Сибирский фредеральный округ, в период 1990-2013 гг. и сорормирован их рейтинг (табл. 3) [8].

Сразу оговоримся, что здесь отсутствуют Северо-Кавказский и Крымский федеральные округа, которые созданы относительно недавно.

Как видно из табл. 3, лидерами являются ЦФО и СЗФО, аутсайдеры - Приволжский и Южный федеральные округа, при этом уровень рациональности их финансирования различается почти в два раза, что способствует росту социальных проблем и приводит к негативным последствиям для РФ. Это отражает то, что на субфредеральном уровне в анализируемом периоде не обеспечивается сопоставимость условий жизнедеятельности для фризических лиц в различных округах [9]. Предположим, что такое положение дел вызвано не объемами финансирования, а иррациональным подходом к осуществлению финансирования (рис. 3).

Таблица 3

\begin{tabular}{|c|c|c|c|c|c|c|c|c|}
\hline $\begin{array}{l}\text { № } \\
\pi / \pi\end{array}$ & $\begin{array}{c}\text { Федеральный } \\
\text { округ }\end{array}$ & Демография & $\begin{array}{c}\text { Социальная } \\
\text { сфрера }\end{array}$ & $\begin{array}{c}\text { Эконо- } \\
\text { мика }\end{array}$ & $\begin{array}{l}\text { Уровень } \\
\text { жизни }\end{array}$ & $\begin{array}{c}\text { Инфра- } \\
\text { структура }\end{array}$ & Финансовые & $\begin{array}{c}\text { Общее } \\
\text { количество } \\
\text { баллов }\end{array}$ \\
\hline 1 & ЦФО & 105 & 74 & 63 & 114 & 106 & 64 & 526 \\
\hline 2 & СЗфО & 74 & 77 & 61 & 108 & 79 & 64 & 463 \\
\hline 3 & ДФО & 49 & 83 & 61 & 55 & 70 & 92 & 410 \\
\hline 4 & УрфО & 77 & 59 & 49 & 57 & 54 & 80 & 376 \\
\hline 5 & СФО & 41 & 94 & 38 & 18 & 42 & 80 & 313 \\
\hline 6 & ПФО & 88 & 52 & 21 & 3 & 50 & 84 & 298 \\
\hline 7 & ЮфО & 85 & 30 & 41 & 3 & 53 & 64 & 276 \\
\hline
\end{tabular}

Рейтинг рациональности финансирования федеральных округов в период 1990-2013 гг. 


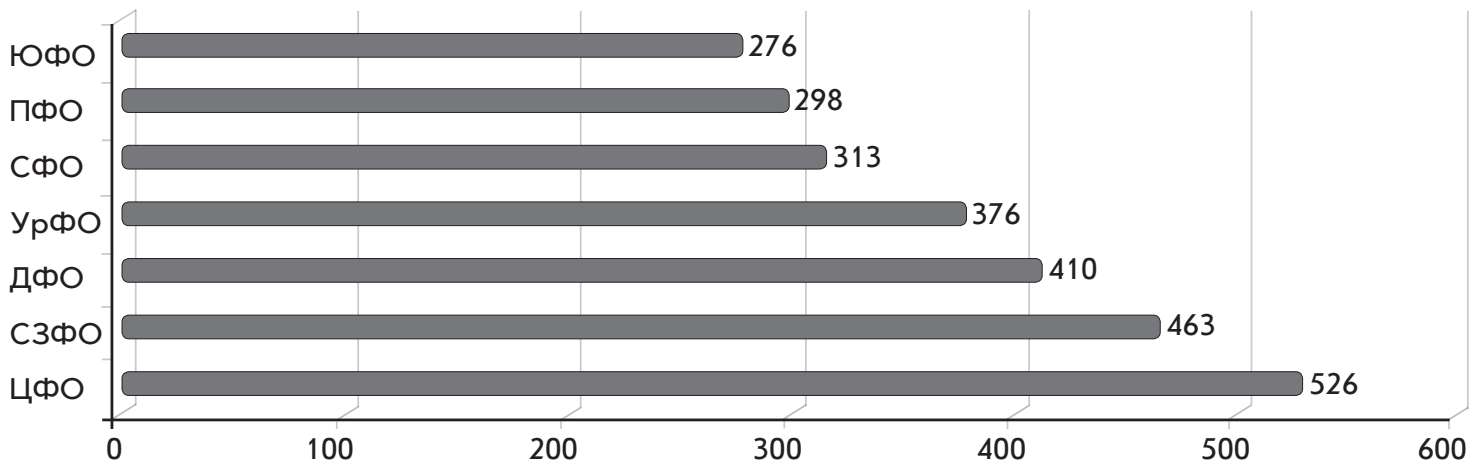

Рис. 3. Уровень рациональности финансирования на субфедеральном уровне, баллов

Рассмотрим, насколько рационально финансирование на уровне субъектов Федерации, входящих в Сибирский федеральный округ. Уровень рациональности фринансирования в Сибирском федеральном округе (табл. 4) очень низок: разница между Алтайским краем с его 245 баллами и Красноярским краем с его 404 баллами составляет почти 40 \%. Следует отметить, что в СФО Красноярский край становится «псевдоцентром» развития, который оттягивает на себя все виды ресурсов. Следует обратить внимание на Новосибирскую область, которая незначительно отстает от лидера, но по очень важному показателю - уровень жизни, и данное отставание почти двукратное, что в условиях оттока населения из сибирских регионов может сыграть решающую роль. Ниже детально рассмотрим округ с позиций развития.
Разработанная нами методика показала, что существующие подходы к финансированию сформировали значительное неравенство в условиях жизнедеятельности в различных субъектах РФ. Фактически, по мнению В. З. Баликоева, «на углубление неравенства регионов серьезно повлияли "обвальный" уход государства из экономики и постепенное выстраивание вертикали власти» [10]. Оценка рациональности финансирования, опирающаяся на предложенную методику, будет способствовать объективной оценке деятельности губернаторов, отталкиваясь от изменений, и определять проблемные направления для осуществления рационального финансирования на основе проектного подхода. Рассмотрим более детально уровень рациональности финансирования по выделенным шести направлениям.

Сравнение субъектов Федерации, входящих в СФО, по рациональности финансирования

Таблица 4 в период 1990-2013 гг.

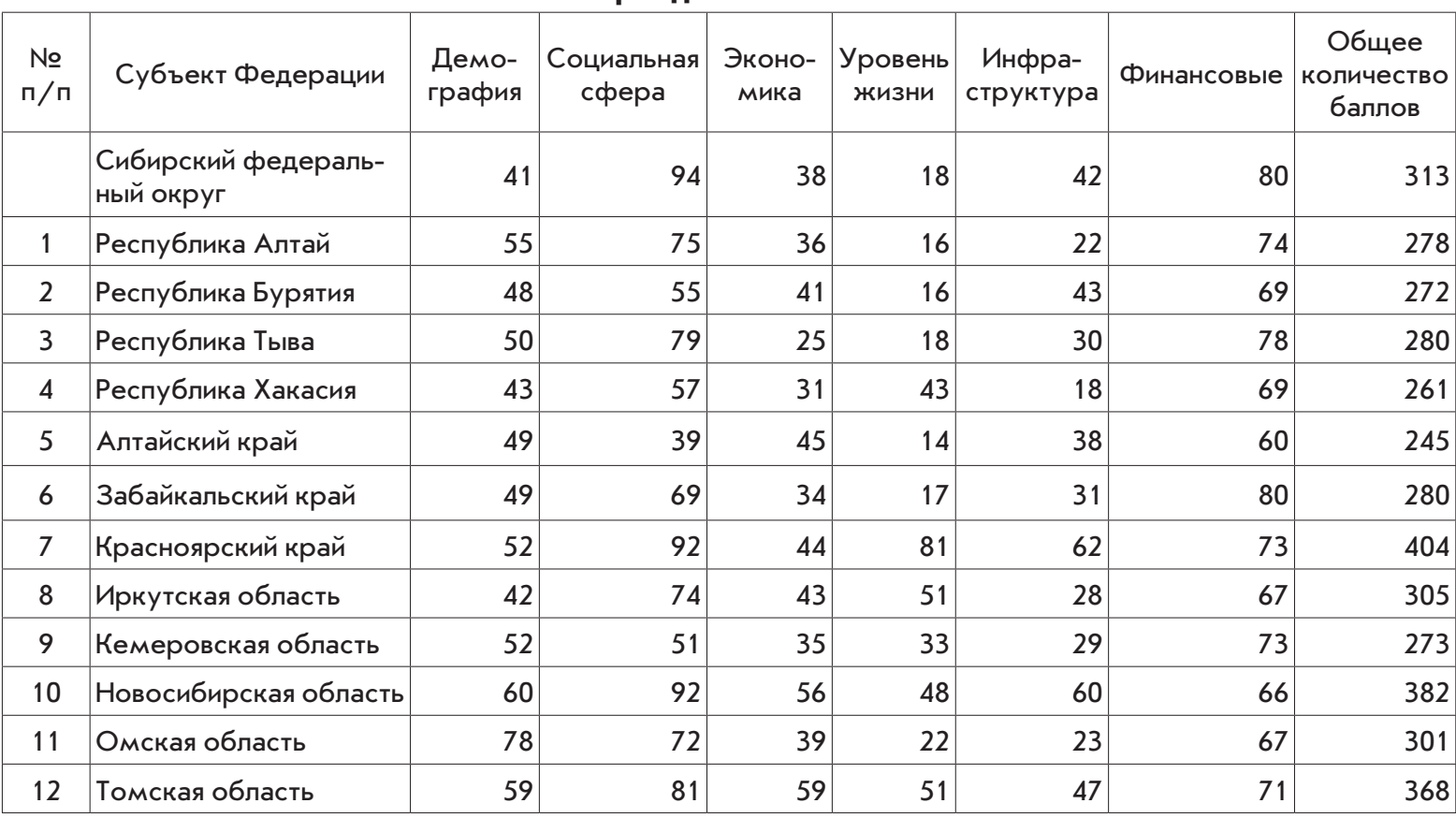




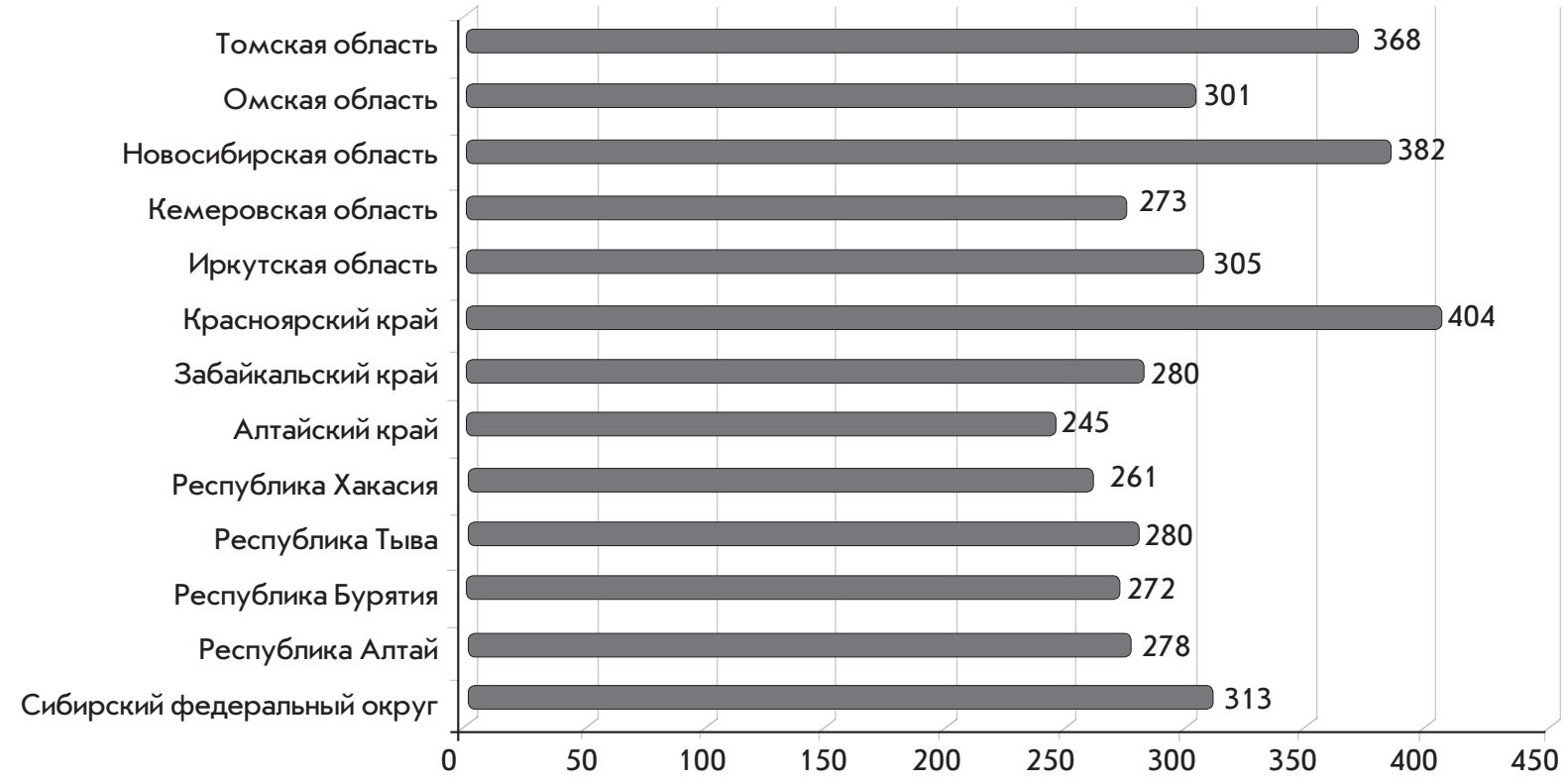

Рис. 4. Уровень рациональности финансирования на уровне Сибирского федерального округа, баллов

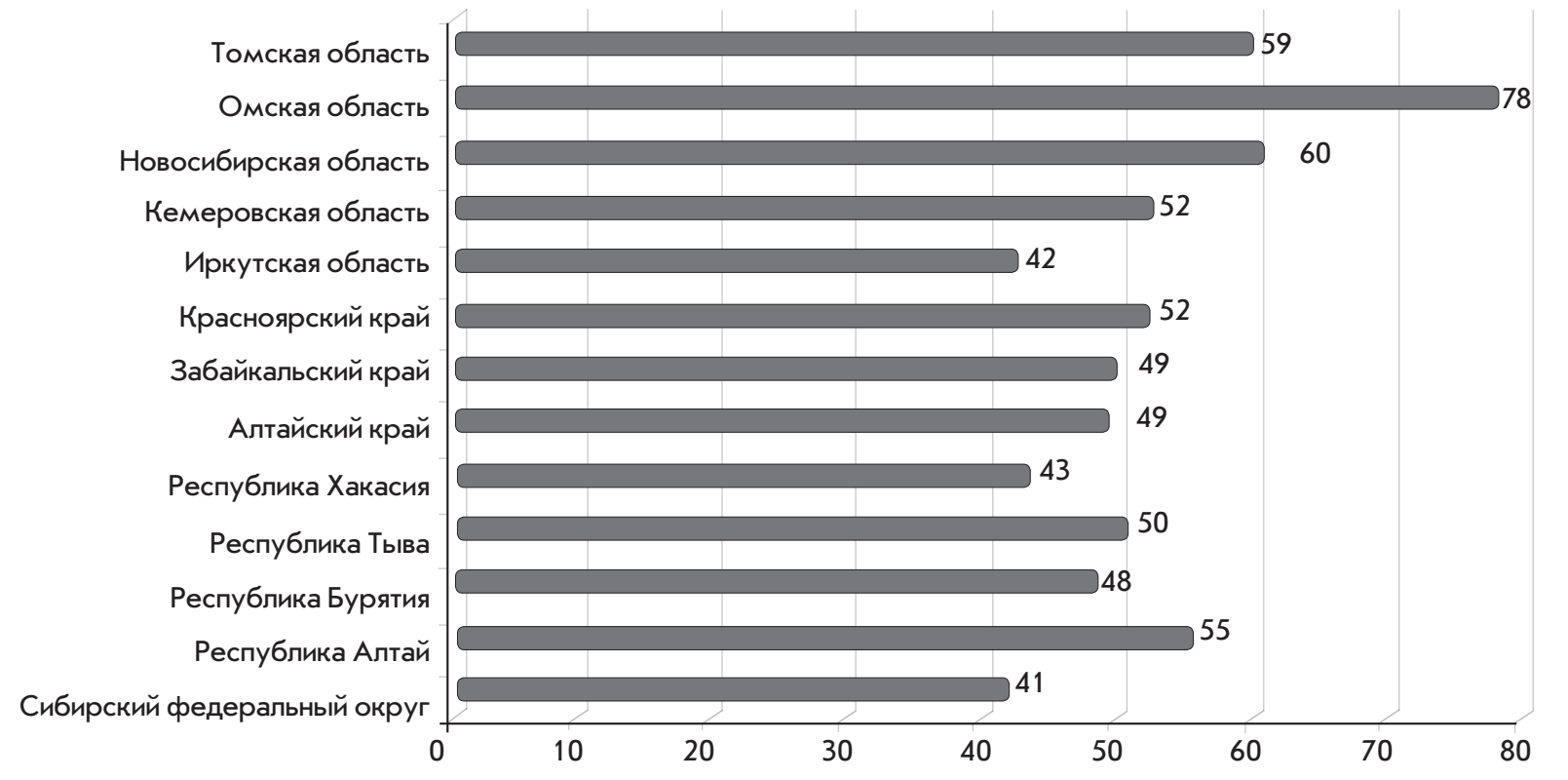

Рис. 5. Уровень рациональности финансирования демографии в Сибирском федеральном округе, баллов

На рис. 5 видно, что Иркутская область с еe 42 баллами является аутсайдером по рациональности фринансирования демографии, а Омская область, набрав 78 баллов, может перераспределить ресурсы на другие направления.

Как демонстрирует нам рис. 6, наибольшее отставание наблюдается в Алтайском крае - 39 баллов, а лидирует Новосибирская область с 92 баллами, что показывает направления рационализации финансирования.

С позиций рациональности финансирования экономики наихудшие результаты в
Республике Тыва - 25 баллов, а наилучшие в Томской области - 59 баллов, что свидетельствует об иррациональности использования финансовых ресурсов (рис. 7).

Уровень жизни является индикатором, определяющим внутреннюю миграцию, при этом Алтайский край с его 14 баллами отстает от лидера - Красноярского края (81 балл) - почти в шесть раз (рис. 8). Данная ситуация будет выражаться в резком притоке населения в Красноярский край. 


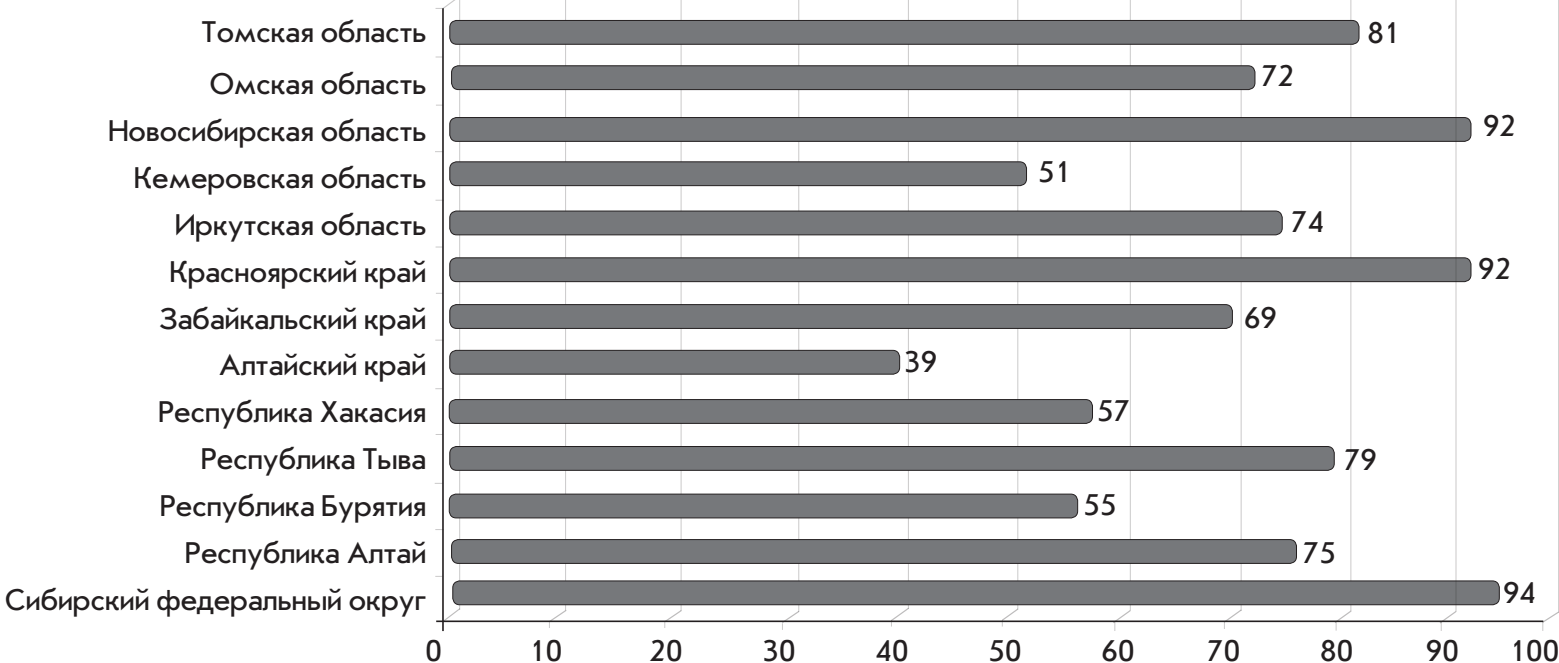

Рис. 6. Уровень рациональности финансирования социальной сферы в Сибирском федеральном округе, баллов

Омская область Новосибирская область

Кемеровская область

Иркутская область

Красноярский край

Забайкальский край

Алтайский край

Республика Хакасия

Республика Тыва

Республика Бурятия

Республика Алтай

Сибирский федеральный округ

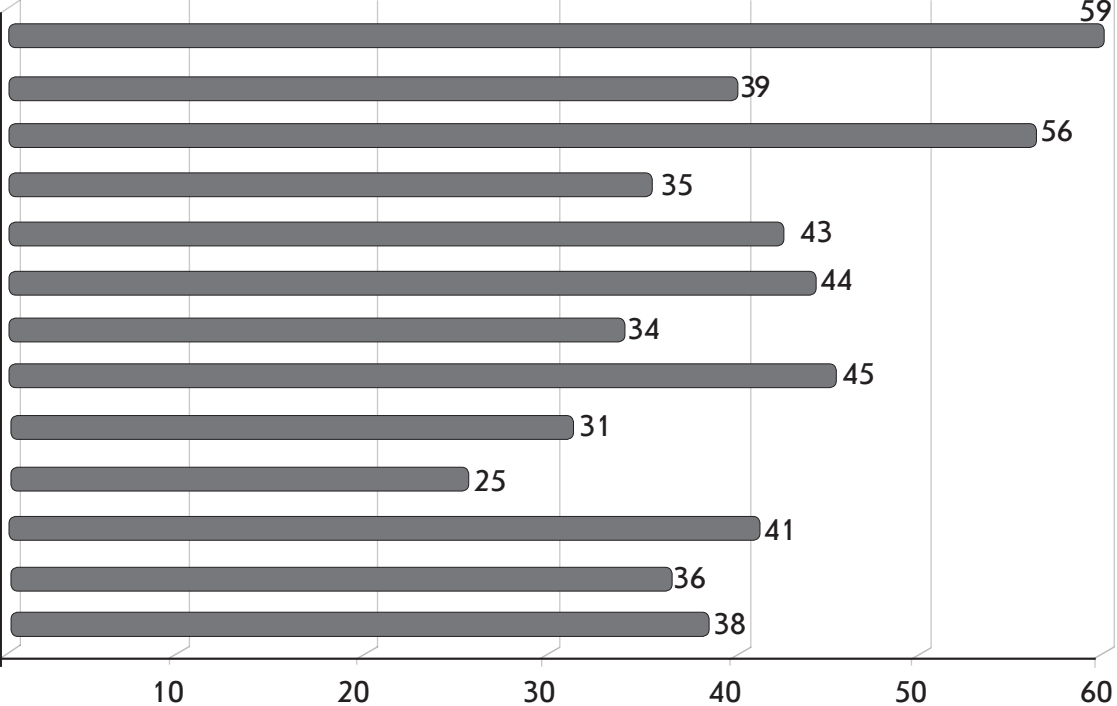

Рис. 7. Уровень рациональности финансирования экономики

в Сибирском федеральном округе, баллов

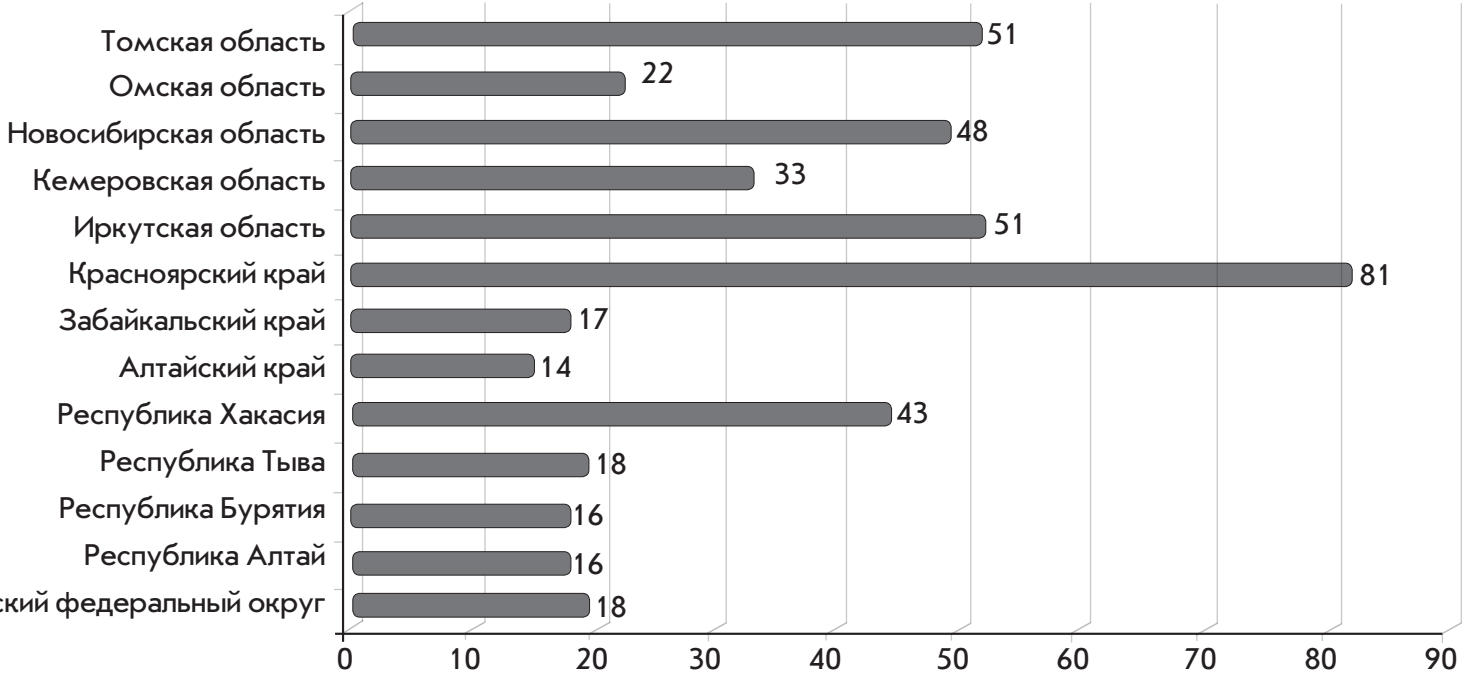

Рис. 8. Уровень рациональности финансирования уровня жизни

в Сибирском федеральном округе, баллов 


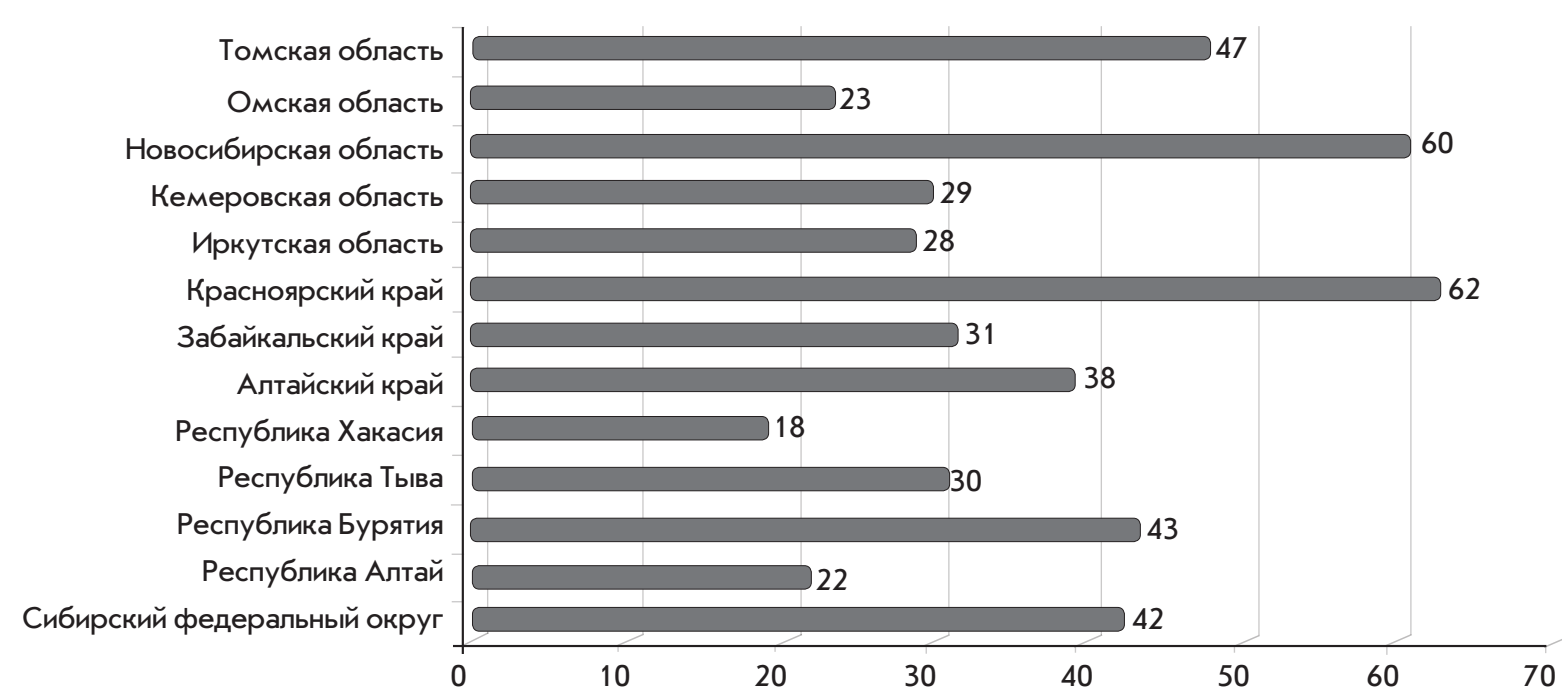

Рис. 9. Уровень рациональности финансирования инфраструктуры в Сибирском федеральном округе, баллов

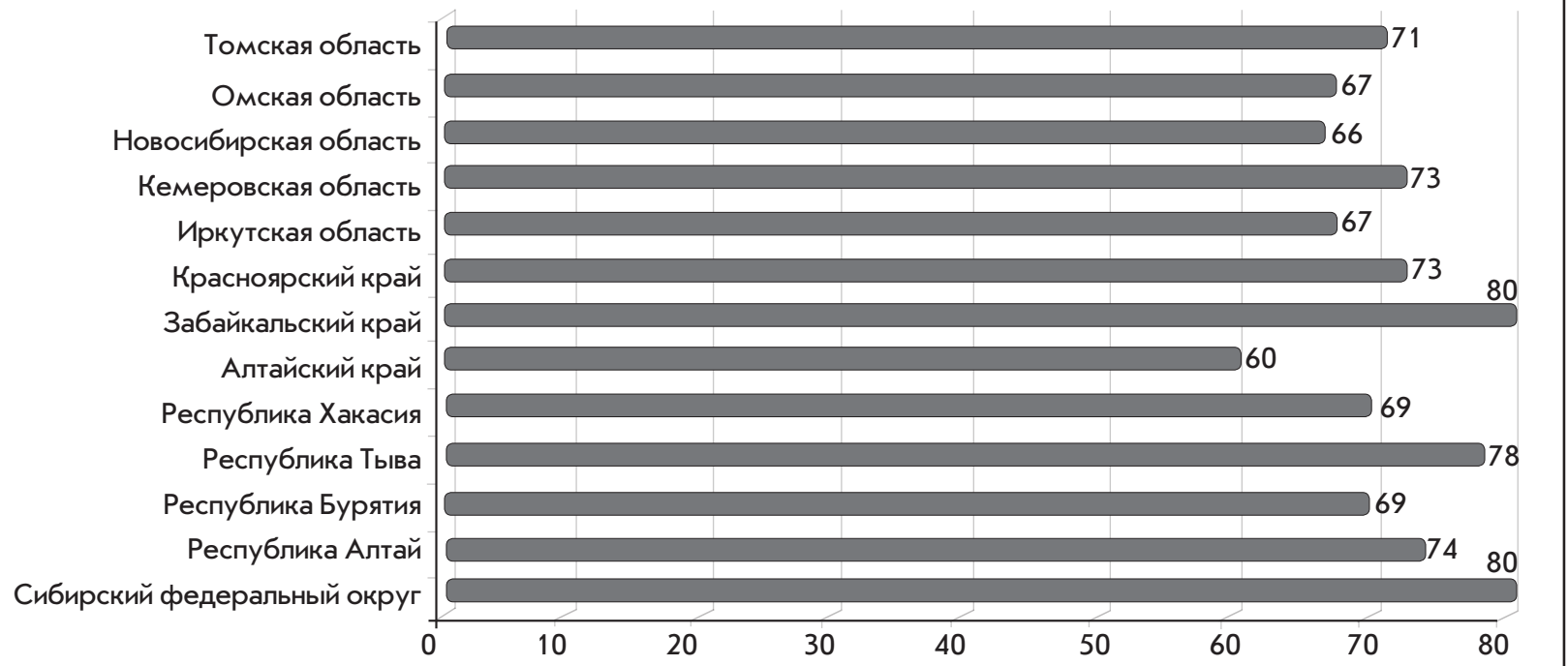

Рис. 10. Уровень рациональности финансирования финансовой сферы Сибирского федерального округа, баллов

Для Сибирского фредерального округа индикаторы, отображающие развитие инфрраструктуры, очень важны в силу удаленности регионов от основных рынков сбыта продукции (рис. 9). При этом Республика Хакасия, имеющая 18 баллов, отстает от лидера - Красноярского края - с его 62 баллами более чем в три раза.

Индикаторы финнансовой сферы не имеют столь существенных различий, что обусловлено прямым влиянием на данные показатели федерального центра (рис. 10).
Рассмотрев шесть направлений, позволяющих оценить уровень рациональности финансирования, можно сделать вывод о формировании в Сибирском фредеральном округе центра развития - Красноярского края. Это приведет к оттоку в него всех видов ресурсов, в том числе человеческих и финансовых, что повлечет за собой деградацию остальных субъектов Федерации. Для исправления негативного тренда следует использовать рациональное фринансирование как инструмент комплексного развития на субфедеральном уровне.

\section{СПИСОК ИСПОЛЬЗОВАННОЙ ЛИТЕРАТУРЫ}

1. Brischoux M. La royauté des economists / M. Brischoux / / Debat. - 2011. — № 166. - P. 138-148.

2. Швецов Ю. Г. Финансовые основы формирования в России социально ориентированного бюджета / Ю. Г. Швецов, О. А. Булаш / / Бухгалтерский учет в бюджетных и некоммерческих организациях. - 2014. № 9 (345). - C. 28-39. 
3. Бубнов В. А. Факторная модель финансирования прироста валового регионального продукта [Электронный ресурс] / В. А. Бубнов / / Известия Иркутской государственной экономической академии (Байкальский государственный университет экономики и права). - 2015. - Т. 6. - № 3. - Режим доступа: http: / /eizvestia. isea.ru/reader/article. aspx?id=20115. - DOI 10.17150/2072-0904.2015.6(3).2.

4. Бубнов В. А. Реформирование налоговой системы на региональном уровне / В. А. Бубнов // Вестник Университета (Государственный университет управления). - 2011. — № 9. - С. 21-26.

5. Тындик А. О. Обзор современных мер семейной политики в странах с низкой рождаемостью / А. О. Тындик // SPERO. - 2010. - № 12. - С. 157-176.

6. Голикова Т. А. Я знаю, куда надо заглянуть [Электронный ресурс] / Т. А. Голикова ; интервьюеры М. Папченкова, Ф. Стеркин / / Ведомости. - 2014. - 18 июня. - Режим доступа: http: / /audit.gov.ru/press_ center/interview / 17960 ? sphrase id $=177491$.

7. Баликоев В. З. Кривая Филлипса: миф или реальность? / В. З. Баликоев // Экономика. - 2012. Май - июнь. - С. 3-10.

8. Бубнов В. А. Формирование экономической привлекательности Сибирского федерального округа / В. А. Бубнов. - Иркутск : Изд-во ИрГУПС, 2009. - 200 с.

9. Бубнов В. А. Методика определения экономической привлекательности федеральных округов Российской Федерации / В. А. Бубнов / / Современные технологии. Системный анализ. Моделирование. - 2012. № 1 (33). - С. 291-295.

10. Баликоев В. З. Как преодолеть региональную асимметрию в России? / В. З. Баликоев, И. Д. Гребенщикова // Экономическое возрождение России. - 2010. - № 3. - С. 6-14.

\section{REFERENCES}

1. Brischoux M. La royauté des economists. Debat, 2011, no. 166, pp. 138-148.

2. Shvecov Yu. G., Bulash O. A. The Financial Basis for the Formation of a Socially Oriented Budget in Russia. Buhgalterskij uchet $v$ byudzhetnyh i nekommercheskih organizaciyah = Accounting in State-Funded and Non-Prof it Organizations, 2014, no. 9 (345), pp. 28-39. (In Russian).

3. Bubnov V. A. Factor Model of Financing of Growth of the Gross Regional Product. Izvestiya Irkutskoi gosudarstvennoi ehkonomicheskoi akademii (Baikal'skii gosudarstvennyi universitet ehkonomiki $i$ prava) $=$ Bulletin of Irkutsk State Economic Academy (Baikal State University of Economics and Law), 2015, vol. 6, no. 3. Available at: http: / / eizvestia.isea.ru/reader/article.aspx?id=20115. DOI 10.17150/2072-0904.2015.6(3).2. (In Russian).

4. Bubnov V. A. Reforming the Tax System at the Regional Level. Vestnik Universiteta (Gosudarstvennyi universitet upravleniya) $=$ Bulletin of the University of the State University of Management, 2011, no. 9, pp. 21-26. (In Russian).

5. Tyndik A. O. Review of Current Measures of Family Policy in Low Fertility Countries. SPERO, 2010, no. 12 pp. 157-176. (In Russian).

6. Golikova T. A. I Know What to Refer to. Vedomosti=Statements, 2014, 18 June. Available at: http: //audit. gov.ru/press center/interview/17960?sphrase id=177491. (In Russian).

7. Balikoev V. Z. Phillips Curve: a Myth or Reality? Ehkonomika = Economics, 2012, May — June, pp. 3-10. (In Russian).

8. Bubnov V. A. Formirovanie ehkonomicheskoi privlekatel'nosti Sibirskogo federal'nogo okruga [Formation of the Economic Attractiveness of the Siberian Federal District]. Irkutsk State Railway Transport Engineering University Publ., 2009. 200 p.

9. Bubnov V. A. Methods of Determining the Economic Attractiveness of the Federal Districts of the Russian Federation. Sovremennye tekhnologii. Sistemnyi analiz. Modelirovanie = Modern Technologies. System Analysis. Modeling, 2012, no. 1 (33), pp. 291-295. (In Russian).

10. Balikoev V. Z., Grebenshchikova I. D. How to Overcome Regional Asymmetries in Russia? Ehkonomicheskoe vozrozhdenie Rossii = Economic Revival of Russia, 2010, no. 3, pp. 6-14. (In Russian).

\section{Информация об авторе}

Бубнов Вячеслав Анатольевич - кандидат экономических наук, доцент, декан факультета менеджмента, логистики и таможенного дела, Иркутский государственный университет путей сообщения, 664074, г. Иркутск, ул. Чернышевского, 15, e-mail: bubnov_v@irgups.ru.

\section{Для цитирования}

Бубнов В. А. Методика определения рациональности финансирования на субфедеральном уровне с позиций равновесия развития / В. А. Бубнов // Известия Байкальского государственного университета. - 2017. - T. 27, № 3. - C. 401-410. - DOI: $10.17150 / 2500-2759.2017 .27(3) .401-410$.

\section{Author}

Vyacheslav A. Bubnov - PhD in Economics, Associate Professor, Dean of Management, Logistics and Customs Faculty, Irkutsk State Railway Transport Engineering University, 15 Chernyshevsky St., 664074, Irkutsk, Russian Federation, e-mail: bubnov_v@irgups.ru.

\section{For Citation}

Bubnov V. A. Methodology of Determing Financing Rationality at the Subfedaral Level in Terms of the Development Equilibrium. Izvestiya Baykal'skogo gosudarstvennogo universiteta $=$ Bulletin of Baikal State University, 2017, vol. 27, no. 3, pp. 401-410. DOl: 10.17150/2500-2759.2017.27.(3).401-410. (In Russian). 